\title{
ВПЛИВ ПЕЧІНКОВОГО МЕТАБОЛІЗМУ В ДІВЧАТОК ПУБЕРТАТНОГО ВІКУ 3 НЕАЛКОГОЛЬНОЮ ЖИРОВОЮ ХВОРОБОЮ ПЕЧІНКИ Й ОЖИРІННЯМ НА БАЗАЛЬНИЙ АНДРОГЕННИЙ ПРОФІЛЬ
}

Вступ. У літературі існують поодинокі дані відносно фрункціонального стану печінки у дівчаток пубертатного віку з неалкогольною жировою хворобою печінки й ожирінням і його впливу на статевий розвиток.

Мета дослідження - вивчити особливості фрункціонального стану печінки у дівчаток пубертатного віку з неалкогольною жировою хворобою печінки й ожирінням та оцінити взаємозв'язок з фрормуванням гіперандрогенних станів.

Методи дослідження. Під спостереженням перебували 120 дівчаток віком 12-17 років з неалкогольною жировою хворобою печінки й ожирінням, а також 180 дівчаток контрольної групи. Комплексне обстеження включало збір анамнезу, антропометрію, клінічні й біохімічні дослідження крові, ультразвукове дослідження і комп'ютерну томографрію черевної порожнини, оцінку клінічного та біохімічного гіперандрогенізму, менструального здоров'я.

Результати й обговорення. У дівчаток з неалкогольною жировою хворобою печінки й ожирінням виявлено порушення вуглеводного, ліпідного, пуринового обміну на тлі збільшення трансфераз. Андрогенозалежні дерматопатії зареєстровано в 51,67 \% дівчаток. Гірсутне число понад 12 балів за шкалою Феррімана - Галлвея виявлено в 37,50 \% випадків, у межах від 8 до 11 балів - у 44,17 \%, від 0 до 7 балів у 18,33 \%. Дівчаток пубертатного віку з неалкогольною жировою хворобою печінки й ожирінням відрізняв підвищений базальний профріль андрогенів периферичної крові. Наявність інсулінорезистентності та гіперандрогенізму призвела до розвитку в досліджуваній групі розладів менструальної функції в період пубертату: в 62,50 \% випадків відзначали олігоменорею, у 27,50 \% - аменорею, в 10,00 \% - рясні менструації, у 14,17\% - дисменорею.

Висновок. У дівчаток пубертатного віку з неалкогольною жировою хворобою печінки й ожирінням порушення печінкового метаболізму провокують розвиток клінічного і біохімічного гіперандрогенізму, який є основою для порушення статевого розвитку та фрормування аномальних змін менструального здоров'я у дівчаток пубертатного віку.

КЛЮчОВІ СЛОВА: дівчатка; статевий розвиток; неалкогольна жирова хвороба печінки; ожиріння; печінковий метаболізм; гіперандрогенізм; менструальне здоров'я.

ВСТУП. Постановка проблеми в загальному аспекті та їі зв'язок із важливими науковими або практичними завданнями. У багатьох цивілізованих країнах світу кількість дітей 3 надмірною масою тіла й ожирінням має тенденцію до збільшення [1-3]. Викликає тривогу той фракт, що з покоління в покоління прискореними темпами накопичується мутагенний вантаж, підвищується чутливість до впливу несприятливих фракторів середовища, знижується вік реалізації мультисракторних захворювань, у тому числі дифузних захворювань печінки. Результати статистичних досліджень свідчать про суттєве омолодження не тільки ожиріння, але і такого захворювання дорослого населення, як неалкогольна жирова хвороба печінки (НАЖХП). У ( Е. Ф. Чайківська, 2020. дитячій популяції в дітей з ожирінням НАЖХП діагностують у 40 \% випадків [4], тоді як у підлітків з ожирінням, ускладненим метаболічним синдромом, цей показник сягає $70 \%$, причому в 13 \% випадків виявляють ознаки неалкогольного жирового стеатозу печінки [5].

Аналіз останніх досліджень і публікацій, в яких починається вирішення проблеми і на які спирається автор. У сучасній літературі дані про функціональні порушення печінки у хворих з ожирінням суперечливі. Ряд авторів стверджує, що при розвитку НАЖХП страждають жовчопродукувальна і жовчосекреторна фуункції внаслідок деструкції мембран гепатоцитів та підвищення рівня печінкових ензимів - трансаміназ (аланінамінотранссрерази (АлАТ), аспартатамінотрансорерази (АсАТ), у-глютамілтранспептидази) [6]. 
Інші автори вважають стеатоз печінки "нешкідливим станом", який не має значного впливу на стан гепатоцитів і проходить після усунення етіологічного фрактора [7].

У літературі існують поодинокі дані відносно фрункціонального стану печінки у дівчаток пубертатного віку з НАЖХП та ожирінням. Водночас відомо, що ожиріння, гіперінсулінемія і гіперандрогенія тісно взаємопов'язані [8]. Підвищений рівень циркулюючих вільних жирних кислот у печінці сприяє гіперінсулінемії. Фактор некрозу пухлини- $\alpha$, що продукується жировою тканиною, призводить до інсулінорезистентності та пригнічення сигнального каскаду інсулінового рецептора. Підвищений рівень інсуліну в сироватці крові сприяє надмірному виробленню андрогенів яєчниками та їх диссункції, що може позначитися на статевому розвитку [6]. Мало вивчено питання щодо впливу печінкового метаболізму при НАЖХП на розвиток гіперандрогенних станів у дівчаток пубертатного віку з ожирінням.

Мета дослідження - вивчити особливості фрункціонального стану печінки у дівчаток пубертатного віку з неалкогольною жировою хворобою печінки й ожирінням та оцінити взаємозв'язок 3 формуванням гіперандрогенних станів.

МЕТОДИ ДОСЛІДЖЕННЯ. Під спостереженням перебували 120 дівчаток віком 12-17 років з НАЖХП і метаболічно нездоровим ожирінням, а також 180 умовно соматично здорових дівчаток контрольної групи з нормальним статевим розвитком та нормальною масою тіла. Комплексне обстеження включало збір анамнезу, антропометрію, клінічні й біохімічні дослідження крові, ультразвукове дослідження органів черевної порожнини, комп'ютерну томографрію черевної порожнини (за показаннями).

При оцінюванні ступеня тяжкості акне застосовували найбільш часто використовувану класисрікацію Американської академії дерматології [9]: І ступінь характеризується наявністю комедонів і до 10 папул; II ступінь - комедонів, папул, до 10 пустул; III ступінь - комедонів, папул, пустул, до 5 вузлів; IV ступінь - вираженою запальною реакцією в глибоких шарах з фрормуванням хворобливих вузлів і кіст.

Оцінювали виразність гірсутизму за "гормональною” шкалою Феррімана - Галлвея (1961) з використанням чотирибальної системи відповідно до локалізації та площини надлишкового росту волосся в 9 зонах: А - верхньої губи, В підборіддя, C - грудей, D - верхньої, E - нижньої частини живота, F - плеча, G - стегон, H - спини, I - попереку.

Визначали базальний вміст андрогенів - загального тестостерону (T), вільного тестостеро- ну (Тв), 17-гідроксипрогестерону (17-ОП), дегідроепіандростерону (ДГЕА), дегідроепіандростерону-сульфрату (ДГЕА-С), андростендіону ( $\triangle \mathrm{A} 4)$, дигідротестостерону (ДГТ), а також глобуліну, який зв'язує статеві гормони (ГЗСГ).

Статистичний аналіз результатів проводили за допомогою програми Microsoft Excel 2010.

РЕЗУЛЬТАТИ Й ОБГОВОРЕННЯ. ПрИ ПрОведенні ультразвукового дослідження печінки дівчаткам-підліткам НАЖХП проявлялася у вигляді підвищення ехогенності паренхіми, її дифузійної неоднорідності, нечіткості судинного малюнка і загасання ультразвукового променя. Результати комп'ютерної томографрії, виконаної 15 хворим з ультразвуковими ознаками НАЖХП, показали, що в усіх дітей структура паренхіми була неоднорідною. При цьому денситометрична щільність незмінених ділянок коливалася від 55 до 60 од. Н., а щільність окремих вогнищ у нативну фразу становила від 15 до 43 од. Н., проте контури не всіх ділянок визначалися під час нативного дослідження. При використанні імпульсної послідовності SPAIR (з пригніченням жиру) гіподенсні ділянки мали низький сигнал. У всі фрази контрастного посилення, в тому числі при відстроченому скануванні, їх щільність, на відміну від ділянок з нормальною паренхімою, змінювалася незначно.

При проведенні комплексного біохімічного обстеження дівчаток з НАЖХП та ожирінням було виявлено порушення вуглеводного, ліпідного, пуринового обміну на тлі підвищення рівня трансфераз, насампередаланінамінотрансорерази, які характеризувалися статистично значимими відхиленнями досліджуваних параметрів відносно аналогічних у контрольній групі (рис. 1).

Ожиріння, зниження чутливості до інсуліну поєднувалися в обстежених дівчаток пубертатного віку 3 НАЖХП та ожирінням 3 клінічним і біохімічним гіперандрогенізмом.

Андрогенозалежні дерматопатії зареєстровано в 51,67 \% (62) дівчаток-підлітків з НАЖХП. Виявлено акне різного ступеня тяжкості, в тому числі: в 45,16 \% (28) пацієнток - І ступеня, у 29,03 \% (18) - II ступеня, в 16,13 \% (10) - III ступеня, в 9,68 \% (6) - IV ступеня. У контрольній групі випадків вугрового висипу відповідно до прийнятої класифрікації не спостерігали.

3 провідних клінічних симптомів клінічного гіперандрогенізму найбільш значущим у діагностиці гіперандрогенії вважають гірсутизм, на відміну від якого вугри і жирна себорея частіше $€$ результатом не надлишкового продукування андрогенів, а змін їх метаболізму в шкірі [10]. У дівчаток з НАЖХП гірсутне число понад 12 балів за шкалою Феррімана - Галлвея виявлено в 


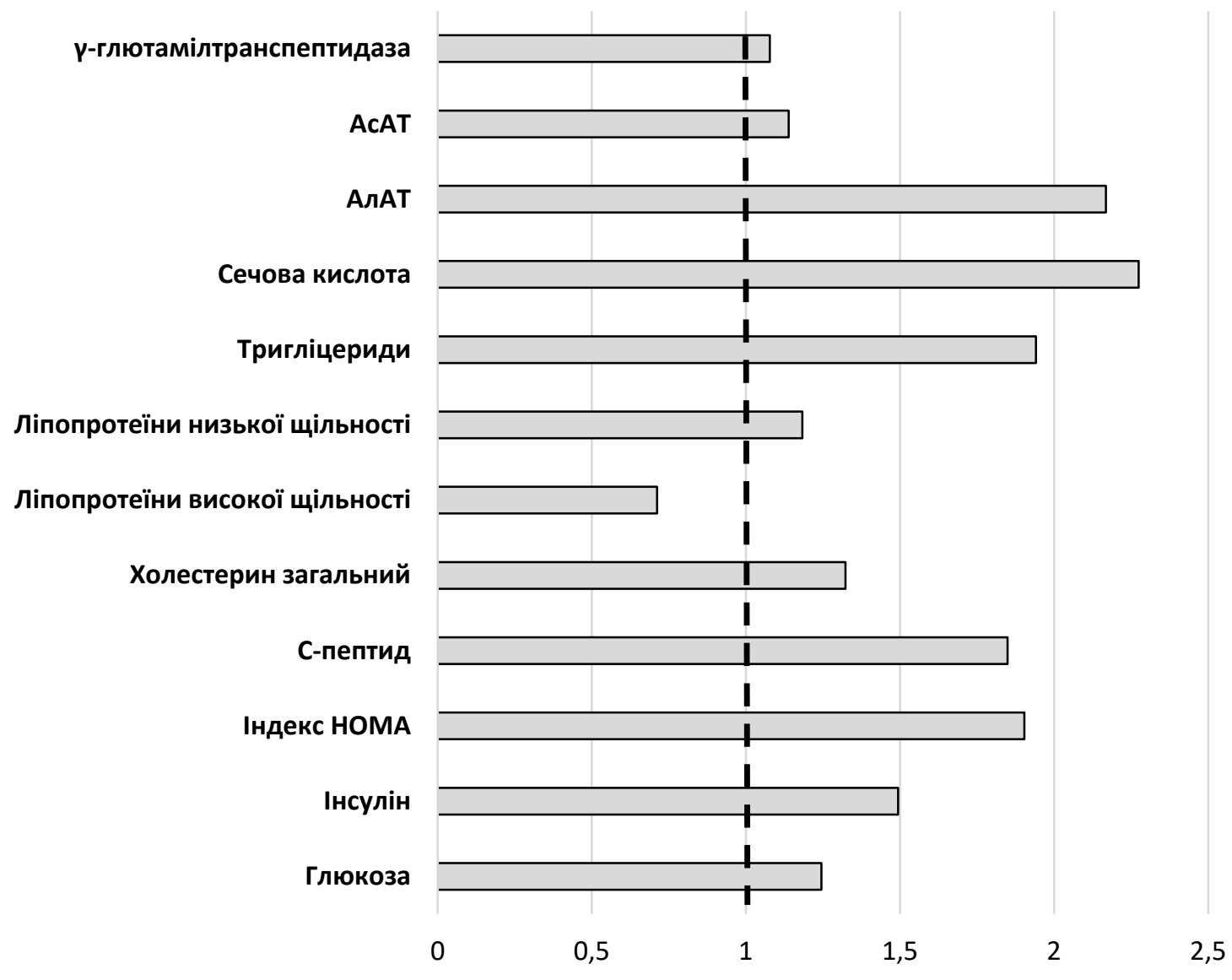

Рис. 1. Зміщення показників біохімічного обстеження пацієнток пубертатного віку з неалкогольною жировою хворобою печінки й ожирінням відносно аналогічних показників контрольної групи.

Примітка. Тут і на рисунках 2, 3: - - - - рівень показника контрольної групи, взятий за одиницю.

37,50 \% (45) випадків, у межах від 8 до 11 балів у 44,17\% (53) випадків, від 0 до 7 балів - у $18,33 \%$ (22) випадків. У контрольній групі в 97,22 \% (175) дівчаток гірсутне число було менше 8 балів, у 2,78 \% (5) випадків - дорівнювало 8-11 балів.

У результаті дослідження наявності біохімічного андрогенізму встановлено, що дівчаток пубертатного віку з НАЖХП та ожирінням відрізняв підвищений рівень ДГТ (72,50 \% (87)), ДГЕА
(57,50\% (69)), ДГЕА-С (45,83\% (55)), $\triangle$ А4 (51,67\% (62)), збільшений рівень Т і Тв визначався значно рідше - відповідно, в 11,67 \% (14) та 21,67 \% (26) пацієнток (рис. 2).

Звертало на себе увагу зниження у всіх вікових категоріях підлітків рівнів ГЗСГ (рис. 3).

Печінка $є$ одним з органів, відповідальних за метаболізм глюкози через вироблення глюкози (глюкогенез), яка зберігається у вигляді глюкогену (глікогенез) і при необхідності розкладаєть-

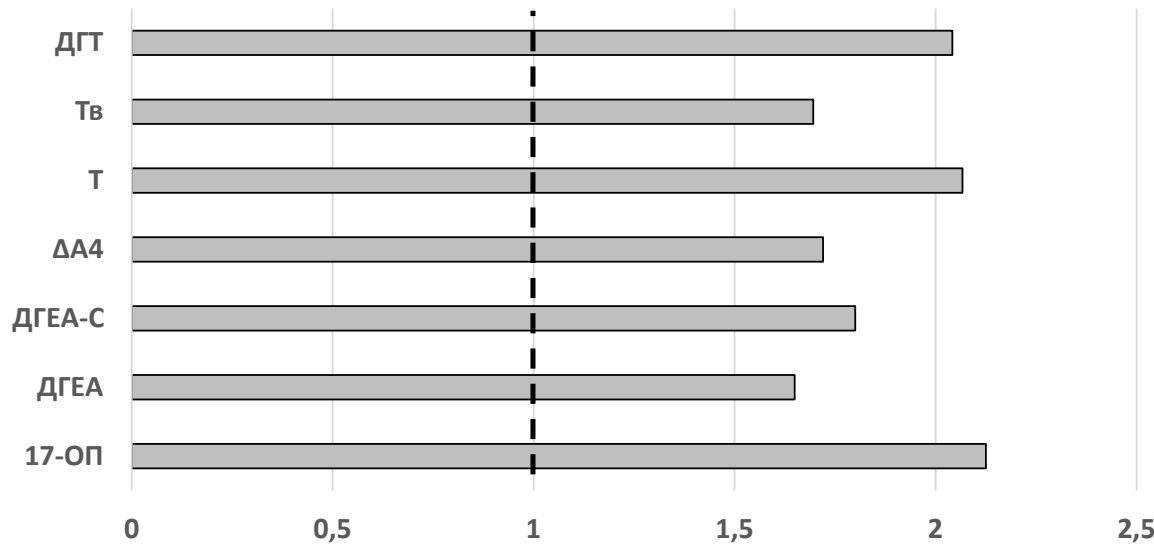

Рис. 2. Зміщення показників базальних андрогенів у пацієнток пубертатного віку з з неалкогольною жировою хворобою печінки й ожирінням відносно аналогічних показників контрольної групи. 


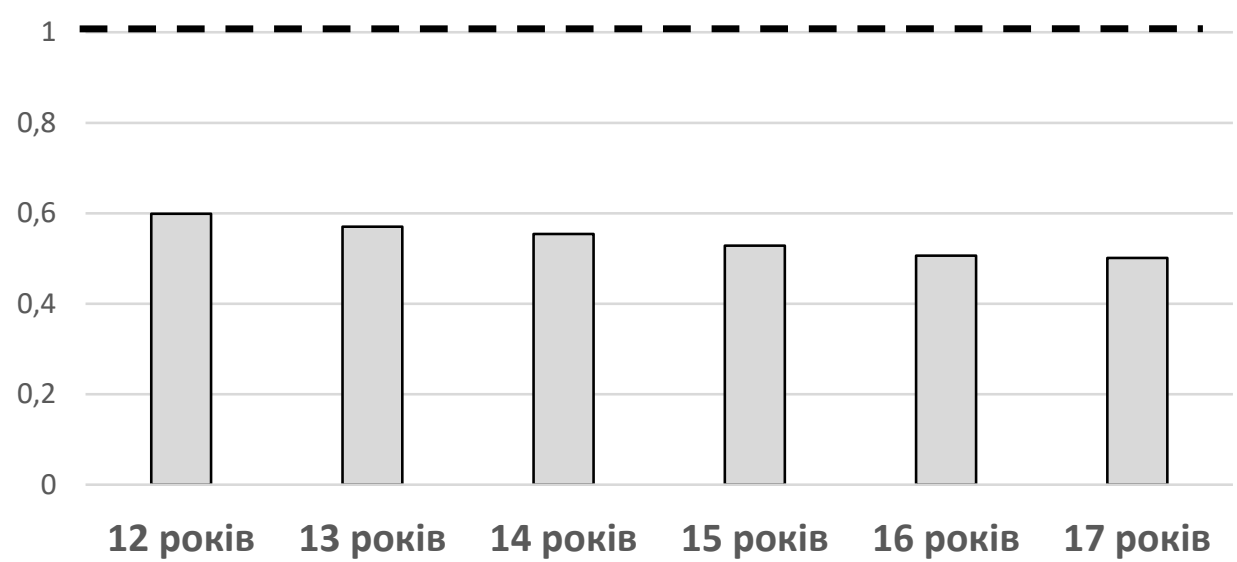

Рис. 3. Зміщення рівня глобуліну, який зв'язує статеві гормони, у пацієнток з неалкогольною жировою хворобою печінки й ожирінням відносно аналогічних показників контрольної групи впродовж пубертатного періоду.

ся за допомогою гліколітичного шляху (глікогеноліз) або перетворюється в жирні кислоти ліпогенним шляхом (ліпогенез). Надлишок інсуліну порушує метаболізм глюкози в печінці в результаті зниження концентрації глюкози в крові через дію інсуліну і синтез глікогену [7]. Гіперінсулінемія - чинник зменшення вмісту ГЗСГ, що призводить до збільшення у сироватці крові рівня вільних і метаболічно активних андрогенів [10], зниження кліренсу андрогенів та активності ароматази, посилення стероїдогенезу. Глобулін, який зв'язує статеві гормони, може функціонувати у дитинстві, обмежуючи дію статевих стероїдів до статевого дозрівання, коли рівень статевих стероїдів підвищується разом із зниженням рівня ГЗСГ у плазмі, так що загальний результат прогресивний - збільшення як загального, так і вільного рівнів статевих гормонів, у тому числі андрогенів [7].

У дівчаток з НАЖХП та ожирінням зниження чутливості до інсуліну підсилює приплив вільних жирних кислот у печінку та змінює і так змінене продукування ліпопротеїнів печінкою, так що концентрація тригліцеридів та ліпопротеїнів низької щільності зростає, тоді як концентрація ліпопротеїнів високої щільності знижується. Зі збільшенням ожиріння спостерігають підвищене продукування маркерів запалення, які, у свою чергу, сприяють подальшому зростанню резистентності до інсуліну. Гіперсекреція інсуліну стимулює вироблення андрогенів тека-клітинами яєчників; андрогени порушують нормальний розвиток фоолікулів, призводячи до множинної атрезії; надлишок інсуліну підсилює викид лютеїнізуючого гормону у відповідь на стимуляцію гіпофріза гонадоліберином, що спричиняє збільшення продукування андрогенів тека-клітинами яєчників [8], крім того, сприяє розвитку в жінок інсулінорезистентності й знижує синтез ГЗСГ печінкою, що зумовлює зростання рівня вільного (біологічно активного) тестостерону.

Проведений кореляційний аналіз підтвердив наявність при НАЖХП прямих зв'язків між рівнями аланінамінотрансорерази і глюкози натще, індексом НОМА, рівнями 17-ОП, ДГЕА-С, Тв та зворотного зв'язку з рівнем ГЗСГ.

Наявність У дівчаток з НАЖХП і нездоровим морбідним ожирінням інсулінорезистентності та гіперандрогенізму призвела до розвитку в досліджуваній групі розладів менструальної фрункції в період пубертату: в 62,50 \% (75) випадків розвинулась олігоменорея, у 27,50 \% (33) - аменорея, в 14,17 \% (17) - дисменорея, рясні менструації були в 10,00 \% (12) пацієнток.

ВИСНОВКИ. У дівчаток пубертатного віку з НАЖХП та ожирінням формуються виражені зміни орерментного, ліпідного, вуглеводного, пуринового обміну, що проявляються у вигляді підвищення рівня інсуліну, С-пептиду, індексу інсулінорезистентності, змін глікемічного просрілю, зниження вмісту ГСЗГ. Усі ці явища провокують розвиток клінічного та біохімічного гіперандрогенізму, який $є$ основою для порушення статевого розвитку та формування аномальних змін менструального здоров'я у дівчаток пубертатного віку.

Перспективи подальших досліджень. Потрібні дослідження, направлені на пошук ефективних лікувально-профрілактичних засобів відновлення печінкового метаболізму у дівчаток-підлітків з неалкогольною жировою хворобою печінки й ожирінням для сприяння нормалізації їх статевого розвитку і менструального здоров'я в пубертаті. 


\section{СПИСОК ЛІТЕРАТУРИ}

1. Бокова Т. А. Метаболический синдром у детей: подходы кпрофилактике и патогенетической терапии / Т. А. Бокова // Лечащий врач. - 2018. - № 9. C. 74-76.

2. Особенности гепатобилиарной системы при ожирении у детей / Е.И.Алешина, М.М.Гурова В. П. Новикова [и др.] // Профилактическая клинич. медицина. - 2012. - № 1. - С. 10-15.

3. Changes in overweight/obesity and central obesity status from preadolescence to adolescence: a longitudinal study among schoolchildren in Japan / $\mathrm{H}$. Ochiai, T. Shirasawa, R. Nishimura [et al.] // BMC. Public Health. - 2020. - 20, No. 1. - P. 241.

4. Харрисон С. А. Повышение активности печеночных ферментов и жировая дистрофия печени / С. А. Харрисон // Клинич. гастроэнтерол. гепатол. 2009. - 2, № 3. - C. 26-31.

5. A guide to non-alcoholic fatty liver disease in childhood and adolescence / J. L. Temple, P. Cordero, J. Li [et al.] // Int. J. Mol. Sci. - 2016. - 15, No. 17 (6). P. 947.

\section{REFERENCES}

1. Bokova, T.A. (2018). Metabolicheskiy sindrom u detey: podhody $\mathrm{k}$ profilaktike i patogeneticheskoy terapii [Metabolic syndrome in children: approaches to prevention and pathogenetic therapy]. Lechaschiy Vrach Attending Physician, 9, 74-76 [in Russian].

2. Aleshina, E.I., Gurova, M.M., Novikova, V.P., Gureva, V.A., \& Usyichenko, E.A. (2012). Osobennosti gepatobiliarnoy sistemy pri ozhirenii u detey [Features of the hepatobiliary system in obesity in children]. Profilakt. Klinich. Med. - Prevent. Clin. Med., 1, 10-15 [in Russian].

3. Ochiai, H., Shirasawa, T., Nishimura, R., Yoshimoto, T., Minoura, A., Oikawa, ..., \& Kokaze, A. (2020). Changes in overweight/obesity and central obesity status from preadolescence to adolescence: a longitudinal study among schoolchildren in Japan. BMC. Public Health, 20 (1), 241. DOI: 10.1186/s12889-020-8343-3.

4. Harrison, S.A. (2009). Povyishenie aktivnosti pechenochnykh fermentov i zhirovaya distrofiya pecheni [Increased activity of liver enzymes and fatty degeneration of the liver]. Klinich. Gastroenterol. Gepatol. - Clin. Gastroenterol. Hepatol., 2 (3), 26-31 [in Russian].

5. Temple, J.L., Cordero P, Li, J., Nguyen, V., \& Oben, J.A.A. (2016). Guide to non-alcoholic fatty liver disease in childhood and adolescence. Int. J. Mol. Sci., 17 (6),947. DOI: 10.3390/ijms17060947.
6. Liu M. Polycystic ovary syndrome and gender identity / M. Liu, S. Murthi, L. Poretsky // Yale J. Biol. Med. - 2020. - 93, No. 4. - P. 529-537.

7. Sex hormone-dependent physiology and diseases of liver / P. Kur, Kolasa-A. Wołosiuk, K. Misiakiewicz-Has, B. Wiszniewska // Int. J. Environ. Res. Public Health. 2020. - 17, No. 8. - P. 2620.

8. Effect of central obesity and hyperandrogenism on selected inflammatory markers in patients with PCOS: A WHtR-Matched Case-Control Study / M. Kałużna, M. Człapka-Matyasik, K. Wachowiak-Ochmańska [et al.] // J. Clin. Med. - 2020. - 9, No. 9. - P. 3024.

9. Guidelines of care for the management of acne vulgaris / A. L. Zaenglein, A. L. Pathy, B. J. Schlosser [et al.] // J. Am. Acad. Dermatol. - 2016. - 74, No. 5. P. 945-973.

10. Rosenfield R. L. The pathogenesis of polycystic ovary syndrome (PCOS): The hypothesis of PCOS as functional ovarian hyperandrogenism revisited / R. L. Rosenfield, D. A. Ehrmann // Endocr. Rev. - 2016. - 37, No. 5. - P. 467-520.

6. Liu, M., Murthi, S., \& Poretsky, L. (2020). Polycystic ovary syndrome and gender identity. Yale J. Biol. Med., 93 (4), 529-537.

7. Kur, P., Kolasa-Wołosiuk, A., Misiakiewicz-Has, K., \& Wiszniewska, B. (2020). Sex hormone-dependent physiology and diseases of liver. Int. J. Environ. Res. Public Health, 17 (8), 2620. DOI: 10.3390/ijerph17082620.

8. Kałużna, M., Człapka-Matyasik, M., WachowiakOchmańska, K., Moczko, J., Kaczmarek, J., Janicki, A., ..., \& Ziemnicka, K. (2020). Effect of central obesity and hyperandrogenism on selected inflammatory markers in patients with PCOS: A WHtR-Matched Case-Control Study. J. Clin. Med., 9 (9), 3024. DOI: 10.3390/ jcm9093024.

9. Zaenglein, A.L., Pathy, A.L., Schlosser, B.J., Alikhan, A., Baldwin, H.E., Berson, D.S., ..., \& Bhushan, R. (2016). Guidelines of care for the management of acne vulgaris. J. Am. Acad. Dermatol., 74 (5), 945-973.e33. DOI: 10.1016/j.jaad.2015.12.037.

10. Rosenfield, R.L., \& Ehrmann, D.A. (2016). The pathogenesis of Polycystic Ovary Syndrome (PCOS): The hypothesis of PCOS as functional ovarian hyperandrogenism revisited. Endocr. Rev., 37 (5), 467-520.

\section{ЛЬВОВСКИЙ НАЦИОНАЛЬНЫЙ МЕДИЦИНСКИЙ УНИВЕРСИТЕТ ИМЕНИ ДАНИЛА ГАЛИЦКОГО}

\section{ВЛИЯНИЕ ПЕЧЕНОЧНОГО МЕТАБОЛИЗМА У ДЕВОЧЕК ПУБЕРТАТНОГО ВОЗРАСТА С НЕАЛКОГОЛЬНОЙ ЖИРОВОЙ БОЛЕЗНЬЮ ПЕЧЕНИ И ОЖИРЕНИЕМ НА БАЗАЛЬНЫЙ АНДРОГЕННЫЙ ПРОФИЛЬ}

\section{Резюме}

Вступление. В литературе существуют единичные данные относительно фрункционального состояния печени у девочек пубертатного возраста с неалкогольной жировой болезнью печени и ожирением и его влияния на половое развитие. 
Цель исследования - изучить особенности функционального состояния печени у девочек пубертатного возраста с неалкогольной жировой болезнью печени и ожирением и оценить взаимосвязь с формированием гиперандрогенных состояний.

Методы исследования. Под наблюдением находились 120 девочек в возрасте 12-17 лет с неалкогольной жировой болезнью печени и ожирением, а также 180 девочек контрольной группы. Комплексное обследование включало сбор анамнеза, антропометрию, клинические и биохимические исследования крови, ультразвуковое исследование и компьютерную томографию брюшной полости, оценку клинического и биохимического гиперандрогенизма, менструального здоровья.

Результаты и обсуждение. У девочек с неалкогольной жировой болезнью печени и ожирением выявлены нарушения углеводного, липидного, пуринового обмена на фроне увеличения трансфераз. Андрогенозависимые дермопатии зарегистрированы у 51,67 \% девочек. Гирсутное число более 12 баллов по шкале Ферримана - Галлвея обнаружено в 37,50 \% случаев, в пределах от 8 до 11 баллов - в 44,17\%, om 0 до 7 баллов - в 18,33 \%. Девочек пубертатного возраста с неалкогольной жировой болезнью печени и ожирением отличал повышенный базальный профиль андрогенов перифрерической крови. Наличие инсулинорезистентности и гиперандрогенизма привело к развитию в исследуемой группе расстройств менструальной фуннкци в период пубертата: в 62,50 \% случаев отмечали олигоменорею, в 27,50 \% аменорею, в 10,00 \% - обильные менструации, в 14,17\% - дисменорею.

Вывод. У девочек пубертатного возраста с неалкогольной жировой болезнью печени и ожирением нарушения печеночного метаболизма провоцируют развитие клинического и биохимического гиперандрогенизма, который является основой для нарушения полового развития и формирования аномальных изменений менструального здоровья у девочек пубертатного возраста.

КЛЮЧЕВЫЕ СЛОВА: девочки; половое развитие; неалкогольная жировая болезнь печени; ожирение; печеночный метаболизм; гиперандрогенизм; менструальное здоровье.

E. F. Chaikivska

DANYLO HALYTSKY LVIV NATIONAL MEDICAL UNIVERSITY

\section{EFFECT OF LIVER METABOLISM IN ADOLESCENTGIRLS WITH OBESITY AND NON-ALCOHOLIC FAT LIVER DISEASE ON BASAL ANDROGENIC PROFILE}

\section{Summary}

Introduction. In the literature, there are sporadic data on the functional state of the liver in adolescent girls with obesity and non-alcoholic fatty liver disease (NAFLD) and its effect on sexual development.

The aim of the study - to learn the features of the functional state of the liver in pubertal girls with non-alcoholic fatty liver disease and obesity and to assess the relationship with the formation of hyperandrogenic states.

Research Methods. 120 girls aged 12-17 years with NAFLD and obesity, as well as 180 girls of the control group were under observation. Comprehensive examination included collection of anamnesis, anthropometry, clinical and biochemical blood tests, ultrasound and computed tomography of the abdominal cavity, assessment of clinical and biochemical hyperandrogenism, menstrual health.

Results and Discussion. In girls with NAFLD and obesity, disorders of carbohydrate, lipid, and purine metabolism were revealed against the background of increased transferases. Androgen-dependent dermopathy was registered in $51.67 \%$ of girls. A hirsute score of more than 12 points on the Ferriman-Gallway scale was found in $37.50 \%$ of cases, in the range from 8 to 11 points - in $44.17 \%$, from 0 to 7 points - in $18.33 \%$. Girls of puberty with NAFLD and obesity were distinguished by an increased basal profile of peripheral blood androgens. The presence of insulin resistance and hyperandrogenism in girls with NAFLD and obesity in the study group led to the development of menstrual disorders during puberty: oligomenorrhea developed in $62.50 \%$ of cases, amenorrhea in $27.50 \%$, heavy menstruation bleeding in $10.00 \%, 14.17 \%$-dysmenorrhea.

Conclusions. In adolescent girls with NAFLD and obesity, disorders of hepatic metabolism provoke the development of clinical and biochemical hyperandrogenism, which is the basis for disorders of sexual development and the formation of abnormal changes in menstrual health in girls of puberty.

KEY WORDS: girls; sexual development; non-alcoholic fatty liver disease; obesity; hepatic metabolism; hyperandrogenism; menstrual health.

Отримано 03.11.20

Адреса для листування: Е. Ф. Чайківська, Львівський національний медичний університет імені Данила Галицького, вул. Пекарська, 69, Львів, 79010, Україна, e-mail: elinachaykivska@gmail.com. 